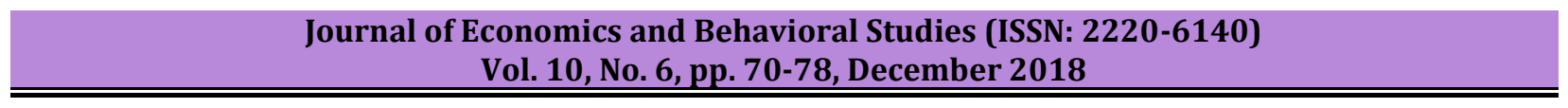

\title{
Determinants of Informal Land Renting Decisions by A1 and A2 Farmers in Mashonaland East Province of Zimbabwe
}

\author{
Simbarashe Tatsvarei ${ }^{1 *}$, Abbyssinia Mushunje ${ }^{1}$, Saul Ngarava ${ }^{1}$, Clifton Makate $^{2}$ \\ ${ }_{1}^{1}$ Department of Agricultural Economics and Extension, University of Fort Hare, South Africa \\ ${ }^{2}$ Africa Centre of Excellence (ACE) for Climate Smart Agriculture and Biodiversity Conservation (Climate SABC), \\ Haramaya University, Dire Dawa, Ethiopia \\ tatsvarei.simbarashe@gmail.com, amushunje@ufh.ac.za,ngaravasaul@gmail.com,ruumakate@live.com
}

\begin{abstract}
Land rental markets are critical in developing economies as they contribute to efficiency, equity and welfare gains to farmers involved under conditions of low transaction costs. Despite lack of policy consistency in Zimbabwe, A1 and A2 farmers have been involved in these land rental markets, albeit in an informal manner. This study sought to establish the determinants of farmers' decision to take part in these informal markets. A survey was carried out in Mashonaland East province with a sample of 339 households selected through multi-stage sampling methods and data analysed using a bi-variate Tobit model. Results showed that combined together, the proportion of farmers involved in informal land rental markets are as much as those not participating. Determinants of renting-in were identified as gender, household income, permanent labour, cultivated area, tenure certainty, irrigable land size and crop diversification. Factors affecting renting-out decisions were age, permanent labour, irrigable land size and crop diversification and these results are not in any way different from findings from previous studies. The conclusion was that household characteristics and land endowments factors were strong in decisions to rent-in land while land endowments factors were dominant in decisions to rent-out land. Any future considerations for formalising land rental markets should consider these important factors having a bearing on land rental decisions.
\end{abstract}

\section{Keywords: Land rentals; $A 1$ and A2 model; bivariate to bit regression; Zimbabwe}

\section{Introduction}

Land tenure has been recognised as an important institutional requirement towards full utilization of agricultural land (Hoken 2012). According to Awasthi (2009), there is a need for low-cost and supple land tenure systems to maximise on the productive use of land and to generate opportunities for agricultural based economies and increased welfare benefits. Under land tenure, usufruct rights in farmland are recognized as a key determinant to agricultural households' poverty levels, food security and vulnerability to shocks (Chamberlin and Ricker-Gilbert 2016). Hagos and Holden (2013) postulated that land rental and sales markets were now very widespread even though traditionally they have not been regarded as features of land tenure systems. This misperception makes studies on land rental policy and market development and their impacts of considerable interest to both researchers and policymakers. Rahman (2010) noted that land rental demands less capital investments when compared to land sales and, in the process, providing superior inter-temporal tractability and giving a chance to owners working off-farm to benefit from on-farm wealth creation activities.

Thus, land rental provides for a win-win situation for both the owners of land and potential farmers who can productively utilise the land. Vranken and Swinnen (2006) argued that in a typical Zimbabwean environment characterised by high risks and high transaction costs, defective credit and insurance markets as well as thin land sales markets, land rental markets provide a viable alternative to full utilization of land. Land rentals are pivotal in improving efficiency and equity in land utilisation and usufruct rights. Theoretically, by equalizing the marginal products of land among households with different land-labour resources, land rental markets subsequently enhance equity and agricultural productivity through transferring the land resource from less to more productive users (Feng 2008). The above literature serves to show that land rental markets are critical in promoting efficient utilisation of land as a resource and in reducing land usage disparities between the landowners and landless but potentially efficient farmers. Understanding of factors likely to influence participation in land rental markets is therefore critical in the promotion of land rental markets as a way of improving farm efficiency and equity. 
Policy makers are able to enhance the success of the operation of rental markets by critically designing institutional arrangements in tandem with those factors that have a bearing on renting-in or renting out of the land (Reid 2016). According to Chamberlin and Ricker-Gilbert (2016), renting-in occurs when farmers utilise additional land from other farmers or those without land access lend from existing landowners while renting-out is when farmers allow potential farmers to utilise their land. Zimbabwe has a strong history with land reforms which dates back to pre-independence (Moyo and Chambati 2013). Four distinct phases of land reforms can be alienated, namely land discrimination on the basis of race (1930-1979), the willing buyer willing seller (1980-1989), the government first refusal of the right to land (1990-1998) and the fast track land reform program (FTLRP) from 2000 to 2010. The FTLRP led to two land tenure models; model A1 mainly aimed at self-sufficiency food and nutrition security and limited marketed surplus production and A2 model, which is a commercial production settlement scheme catering for small, medium and large-scale commercial farming (Matondi and Dekker 2011). However, most of these resettled farmers either lacked appreciation of farming as a business or were not adequately capitalised to undertake farming activities. As a result, agricultural production plummeted in the country with the country resorting to food imports from once being the breadbasket of Southern Africa (Moyo and Chambati 2013).

By 2003 , approximately 222,000 ha of land was under cultivation, implying a decrease of about $50 \%$ compared to the period prior to FTLRP, with tobacco, maize, soybean and wheat being the most affected. Beef declined to a fifth of the year 2000 levels, milk by $36 \%$, poultry by $25 \%$ and piggery by $70 \%$ during the same period (Moyo 2007). In 2007, the government introduced land rentals aimed at encouraging productive use of the land. The rentals were set at US $\$ 15$ for A1 farmers irrespective of the size of land and US $\$ 5$ per hectare per annum for A2 farmers (Government of Zimbabwe 2016). In the aftermath, resettled farmers began to have private arrangements to rent-out and rent-in land in light of required government rental payments, with potential tenants being both former white commercial farmers and indigenous blacks. A study by Matondi and Dekker (2011) in Shamva showed the prevalence of renting in/out among A2 farmers at 18\% compared to A1 farmers at $7 \%$ and 3-tier farmers at $4 \%$. The study also concluded that some farmers were multiple owners of land, with some giving their plots to children or relatives, in some cases bartering for agricultural produce share. While the majority of A1 and A2 farmers were renting-out land without any authority (informal), some have entered into formal partnership arrangements with tenants and some have allocated resettled land to relatives.

Another study by Scoones et al. (2011) in Masvingo showed that A1 and A2 farmers experienced an influx in cattle holdings as part of sharing (kuronzera) arrangement. Communal farmers failing to get adequate grazing areas for their cattle would give their friends or relatives with good grazing pastures cattle to keep. In return, the resettled farmers were allowed to use the cattle for both household and farming activities and sometimes were offered a heifer as a token of appreciation. The existing land rental markets are mainly informal, with government indicating its illegality but turning a blind eye to the practices. The prevalence of the practice has increased after the adoption of the multi-currency system in 2009 and gazetting of land rental payments to the state, putting pressure on farmers to look for alternative income sources to pay for these rentals. This paper therefore aims to unravel the dynamics of informal land rental market participation in Zimbabwe, by analysing the determinants of land renting-in and renting-out decisions among resettled farmers in the province of Zimbabwe. The rest of the article is organised as follows; section 2 outlines the theoretical framework adopted in this paper. Section 3 and 4 give the research methodology and results plus discussions respectively, while Section 5 concludes the research article.

\section{Theoretical Framework}

Previous theoretical assessment studies (Chamberlin and Ricker-Gilbert 2016, Deininger and Jin 2009) have shown that there is the potential of rental markets in enhancing farm efficiency by bringing into equilibrium land and other factor ratios among different households even when other factor markets are not perfect. Household characteristics, land endowments and transaction costs associated with land rental contracts have also long been acknowledged in literature as important factors in the decisions to rent-in or rent-out land (Hagos and Holden 2013). Transaction costs arise due to the need to monitor tenants' behaviour, plus the renter's management practices and potential mismanagement. Additional transaction costs comprise the costs of bargaining, searching for partners, and enforcing contracts (Hagos and Holden 2013). 
These types of transaction costs are particularly high in environments where land rights are not secure (Chamberlin and Ricker-Gilbert 2016) and where the land transfer is controlled (Kimura et al. 2011). Despite the apparent evidence of beneficial contributions of rental markets, well-established perceptions remain that land rental markets could contribute to land concentration and amplified poverty levels, which then justifies the need for close government policing of land rental markets. There are three ways in which smallholder farmers are impacted by land rental markets according to theory (Hagos and Holden 2013), namely equity, efficiency, and welfare. These ultimate outcomes are achieved within the context of moderating factors, which are governance (policy administration and macro-environment), farmer practices, land use as well as capital and land markets. Equity gains are achieved from the reallocation of land across households with varied assets, which process occurs in a way that likely equilibrates land and non-land factor ratios (Hagos and Holden 2013). The efficiency gains are achieved when land is transferred from less productive to more productive users.

\section{Methodology}

Study Area and Sampling: The study was conducted in Mashonaland East Province of Zimbabwe which has an estimated 326825 households and an average household size of 3.1. Population density is 42 persons per square kilometre and $86 \%$ of the population is rural. There are $17731 \mathrm{~A} 1$ and $4700 \mathrm{~A} 2$ households (Zimbabwe National Statistics Agency 2012) and they are mainly concentrated in four out of nine districts. The other districts are mainly populated by communal farming areas. The province was selected for the study as it is one of three provinces in the country which had the highest number of FTLRP beneficiaries. Key informant interviews also revealed that land renting practices are relatively higher for A1 and A2 farmers in this Province compared to other provinces. The study was carried out through the survey method coupled with key informant interviews and focus group discussions. For calculation of sample size, the population was considered as all A1 and A2 households in Mashonaland East, which stands at 22431 (Zimbabwe National Statistics Agency 2012). The main considerations made in calculating the sample size were the margin of error and the significance level. In order to calculate the sample size, the following formula was used (Lefever, Dal, and Matthiasdottir 2007).

$$
\begin{aligned}
& \boldsymbol{n}=\frac{\boldsymbol{X}^{2} * N * \boldsymbol{P} *(\mathbf{1}-\boldsymbol{P})}{\left[\boldsymbol{M E ^ { 2 } * ( \boldsymbol { N } - 1 ) ] + [ \boldsymbol { X } ^ { 2 } * \boldsymbol { P } * ( 1 - P ) ]}\right.} \\
& \text { Where: } \\
& \mathrm{n}=\text { Sample size } \\
& \quad \mathrm{X}^{2}=\text { Chi-square for the specified confidence level at } 1 \text { degree of freedom } \\
& \mathrm{N}=\text { Population Size } \\
& \mathrm{P}=\text { Population proportion (assumed at } 0.5 \text { ) } \\
& \text { ME = desired Margin of Error (expressed as a proportion). }
\end{aligned}
$$

Considering the given population and the aforementioned margin of error and significance level, a sample of size of 378 households was generated. The sample size was reduced to 339 after data cleaning. The sample was prorated for A1 and A2 farmers and for Goromonzi and Marondera districts, as these have highest resettlement beneficiaries. Multi-sampling methods were used to capture critical aspects of the study, with stratified sampling used to select particular A1 and A2 farmers, simple random sampling being used in selecting the wards and purposive sampling used for selecting those involved in renting-in and renting out. A questionnaire was used to collect household data while guides were used to collect key informant and focus group discussion data. Data from the survey was transcribed to CsPro 5 and analysed using Stata.

Tobit Regression Model: Most of the studies on land rental market participation uses either Probit (Shifa 2016) or Tobit models (Bizimana 2011, Hou, Huo, and Yin 2017, Rahman 2010). Those using Probit had a binary variable as the dependent variable while Tobit models tend to have a dependent variable that quantifies the extent of rental participation in terms of the size of the land. Following the study by Rahman (2010) this study also hypothesizes a chronological order of decision making where a farmer makes the decision first to get involved in land rent markets followed by the decision of the size of the transaction. A censored regression model (bivariate Tobit model) is regarded as the appropriate model to use to identify the determinants of renting behaviour. 
Where participation observations (above and below limit) are taken into account. The bivariate model analyses renting-in and renting-out decisions within the same model and not as two separate models. The specific estimation is given as follows:

$\mathrm{y}_{\mathrm{i}}=\alpha_{0}+\mathrm{x}_{\mathrm{i} \beta}+\mathrm{z}_{\mathrm{i}} \gamma+\mathrm{r}_{\mathrm{i}} \delta+\varepsilon_{\mathrm{i}}$

where: $\mathrm{y}_{\mathrm{i}}$ is the dependent variable; $\mathrm{x}_{i}, \mathrm{z}_{\mathrm{i}}$, and $\mathrm{r}_{\mathrm{i}}$ are vectors of variables measuring household characteristics, land endowment characteristics, and transaction cost effects respectively; $\beta, \gamma, \delta$ are vectors of parameters related to the household characteristics, the land endowment characteristics, and transaction cost variables, respectively, and $\varepsilon_{i}$ is an error term (Rahman 2010). The selection of the bi-variate Tobit model was based on extensive literature review and considerations for best fit models. Farmers renting-out land in most cases do not let all of it but remain with some land for their own production. A number of farmers also rent-in land not just as tenants but also own some of the land, which they were fully utilizing and therefore landlords are also tenants in some situations. Accepted reality is also that some farmers are multiple landowners in different locations (Matondi and Dekker 2011) therefore they might be tenants in some physical locations and landlords in others. Moreover, the data showed that there is a strong correlation between the amount of land rented-in and that rented-out, with Spearman's rho value of -0.256 and a two-tailed significance $(\mathrm{p}<0.01)$. Consequently, a bi-variate Tobit model was used as opposed to separate models for renting-in and renting out. The factors used in the model and their explanations are given in table 1:

Table 1: Tobit Model Variables

\begin{tabular}{ll}
\hline Variables & Explanation \\
\hline Land_rented_IN & Land rented in per farm in Ha \\
Land_rented_OUT & Land rented out per farm in Ha \\
Gender & Gender of household head; $1=$ Male, 0 otherwise \\
Marital status & $=1$ if household head is married 0 otherwise \\
Age & Age of household head in years \\
Num_Edu_yrs & Number of years in formal education \\
total_Hh_incom & Estimated total income for a household per year in USD \\
Total_F_members & Total number of resident family members \\
Permanent_labor & Number of permanent labour \\
Cultivated_area & Size of cultivated area in Ha \\
TenureCertainity & Security of tenure=1, 0 otherwise \\
Irrigable_landsze & Size of irrigable land per farm in Ha \\
Crop_Dive_Index & Crop Diversification Index $0=$ complete specialization, 1=perfect \\
Setlmnt_A1 & diversification \\
Capital_value_Assets & Type of settlement=1 A1 Model 0 otherwise \\
Livestock_value_Assets & Value of farm capital assets \\
\hline
\end{tabular}

Following the studies by Hou et al. (2017); Shifa (2016) and Rahman (2010) the variables that were included in the model were shown in the table as well as the explanations. The interpretation of the results was based on the signs of the coefficients and their likelihood to affect the decision to rent in or out. That likelihood is measured by the t-ratio and the significance of each variable is them measured using the t-test.

\section{Results and Discussion}

Goromonzi district had $67.6 \%$ of the farmers while Marondera had 32.4\%, reflecting on the distribution of beneficiaries in the two districts. The sampled farmers were all taken from a total of 8 wards covering these 
two districts. Of the total sample, $78.5 \%$ were from A1 settlement model while $21.5 \%$ were from the A2 resettlement model. Results showed that most of the households were male-headed (79.9\%), while only $20.1 \%$ was being headed by females. The majority of the households also were couples (82\%), with $14 \%$ indicating that they were widowed. Agriculture was the main source of income for the sampled households (77\%), followed by pensioners (8.8\%) and formal employment $(8.3 \%)$, while $4.1 \%$ was involved in informal trading activities. In terms of the land rental activities being involved, 51.3\% was not involved at all in land markets (autarky). A combined $22.2 \%$ was involved in some way in renting-in activities, while $26.5 \%$ was involved in renting-out activities.

Descriptive Statistics of Variables Considered in the Model: The factors that have been considered, which have a bearing on farmer's decision to rent-in or rent-out land are shown in Table 2. These are categorised into farmers not involved in land rentals (autarky), renting-in and those renting-out.

Table 2: Descriptive Statistics for Variables used in the Model

\begin{tabular}{llll}
\hline Variable & Autarky & Renting-in & Renting-out \\
\hline Setlmnt_A1 & 0.839 & 0.773 & 0.689 \\
Gender & 0.816 & 0.773 & 0.789 \\
Marital status & 0.833 & 0.773 & 0.833 \\
Age & 55.672 & 57.813 & 58.656 \\
Num_Edu_yrs & 9.584 & 10.040 & 9.533 \\
total_Hh_incom & 9818.793 & 20993.333 & 95745.000 \\
Total_F_members & 5.224 & 5.667 & 5.222 \\
Permanent_labor & 1.126 & 3.147 & 3.211 \\
Cultivated_area & 3.968 & 20.360 & 15.212 \\
Capital_value_Assets & 5298.621 & 19452.427 & 16381.167 \\
Livestock_value_Assets & 5983.753 & 4552.760 & 5996.178 \\
Tenure certainty & 0.477 & 0.520 & 0.444 \\
& & & \\
Irrigable_landsze & 4.608 & 23.408 & 33.542 \\
& & & \\
Land_rented_IN & 0 & 19.636 & 0 \\
Rental_Amnt_IN & 0 & 64.424 & 0 \\
Land_rented_OUT & 0 & 0 & 20.988 \\
Rental_Amnt_OUT & 0 & 0 & 75.581 \\
Crop_Dive_Index & 0.805 & 0.700 & 0.796 \\
\hline Soure(SUrVy, 2017) & & &
\end{tabular}

Source (Survey, 2017)

Results in table 2 showed the means for the variables across the different farmer categories. For most of the variables, there appeared not to be much difference in their measurements. Also, permanent labour was lowest for farmers in autarky. Land farm size, cultivated area and capital assets were all lowest for farmers in autarky compared to those farmers either renting-in or renting out.

Determinants of Renting-In and Renting-Out Land: The study used a bivariate Tobit model to understand the factors that have a bearing on farmer decision making to rent-in or rent-out land. The results of Tobit model analysis are shown in Table 3.

Table 3: Determinants of Participation in Land Rental Markets (Likelihood Ratios)

\begin{tabular}{lll}
\hline Variables & (Land rented-in) & (Land rented-out) \\
\hline \multirow{2}{*}{ Gender } & & \\
& $5.974^{* *}$ & -6.505 \\
Married & $(2.781)$ & $(4.536)$ \\
& -2.992 & 3.301 \\
Age & $(2.927)$ & $(4.655)$ \\
& 0.031 & $-0.239^{* *}$ \\
& $(0.072)$ & $(0.115)$
\end{tabular}




\begin{tabular}{|c|c|c|}
\hline \multicolumn{3}{|c|}{$\begin{array}{c}\text { Journal of Economics and Behavioral Studies (ISSN: 2220-6140) } \\
\text { Vol. 10, No. 6, pp. 70-78, December } 2018 \\
\end{array}$} \\
\hline Num_Edu_yrs & $\begin{array}{l}0.183 \\
(0.186)\end{array}$ & $\begin{array}{l}0.143 \\
(0.294)\end{array}$ \\
\hline total_Hh_incom & $\begin{array}{l}-0.000^{* * *} \\
(0.000)\end{array}$ & $\begin{array}{l}0.000 \\
(0.000)\end{array}$ \\
\hline Total_F_members & $\begin{array}{l}-0.013 \\
(0.397)\end{array}$ & $\begin{array}{l}-0.824 \\
(0.633)\end{array}$ \\
\hline Permanent_labor & $\begin{array}{l}-1.418^{* * *} \\
(0.269)\end{array}$ & $\begin{array}{l}3.155^{* * *} \\
(0.433)\end{array}$ \\
\hline Cultivated_area & $\begin{array}{l}0.415^{* * *} \\
(0.046)\end{array}$ & $\begin{array}{l}-0.014 \\
(0.073)\end{array}$ \\
\hline TenureCertainity & $\begin{array}{l}3.521^{*} \\
(1.953)\end{array}$ & $\begin{array}{l}1.877 \\
(3.099)\end{array}$ \\
\hline Irrigable_landsze & $\begin{array}{l}0.117^{*} \\
(0.063)\end{array}$ & $\begin{array}{l}-0.239^{* *} \\
(0.101)\end{array}$ \\
\hline Crop_Dive_Index & $\begin{array}{l}7.204^{*} \\
(3.844)\end{array}$ & $\begin{array}{l}17.616^{* * *} \\
(6.070)\end{array}$ \\
\hline sigma1 & $\begin{array}{l}14.225^{* * *} \\
(0.758)\end{array}$ & \\
\hline sigma2 & $\begin{array}{l}22.613^{* * *} \\
(1.206)\end{array}$ & \\
\hline atan_rho & $\begin{array}{l}-0.253^{* *} \\
(0.115)\end{array}$ & \\
\hline Observations & 339 & 339 \\
\hline Log likelihood $=$ & -1572.492 & \\
\hline Wald chi2(11) = & 218.26 & \\
\hline Prob $>$ chi $2=$ & 0.0000 & \\
\hline
\end{tabular}

Source (Survey, 2017), Figures in parenthesis are standard errors

The study used a bivariate Tobit model to analyse the factors influencing farmer decision making to rent-in or rent-out land. The farmers that were considered were only those that are involved in land rental markets, either renting-in or renting out. The log likelihood ratio, which is analogous of the F-test in multiple regression $(\mathrm{p}<0.01)$ was significant. The results in Table 3 showed that compared to women, the likelihood of renting-in land is increased 5.974 times if the household head is male. This result is significant at $5 \%$ level. According to Bert et al. (2015) men are likely to take risks and seek more land for expansion purposes rather than be content with the allocated land, when compared to female heads of households. In addition, results have also shown that a significant number of households not allocated land but participating in rental markets were male-headed. The findings contrast that of Shifa (2016) who concluded that males are less likely to be involved in renting-in compared to their female counterparts. Ensuring more certainty to land rental markets through government policy such as formalising the markets might provide possible solution towards encouraging female-headed households to participate in these markets. A lower income has the effect of not changing much the likelihood of a farmer renting-in land. This is significant at $1 \%$ level of confidence. Given statistics that have shown that $67 \%$ of households depend on agriculture for their income, renting-in therefore provided a means through which farmers could increase their household incomes.

Also, an increase in permanent labour by one unit reduced the likelihood of a farmer renting-in land by 1.418 points. In production economies (Rahman 2010), farmers who have more permanent labour are mostly those with higher levels of productivity. As such they are likely to seek more land to rent in. The results therefore were a deviation from this expected norm. A possible explanation for this deviation is that farmers who were capital intensive (less labour) were more likely to seek more land (renting-in) in order to achieve economies of scale from the available capital. Another reason could be that those farmers who were renting-in but do not have land of their own (consequently fewer permanent workers) were more involved in renting-in than those allocated land by the state. Indeed Moyo (2016) argued that farmers involved in renting-in activities tend to have reduced number of permanent workers. An increase in cultivated area by one unit (hectare) is likely to increase the likelihood of renting-in by 0.148 points. A farmer with a higher hectarage of cultivated land was 
more likely to be fully utilizing the landholding and be more efficient by taking advantage of economies of scale (Rahman 2010).

Therefore, such a farmer was likely to rent-in more land after fully utilising all allocated land and then start to look for underutilized land among fellow farmers. Even for those farmers renting-in but not owning any land, participation in rental markets required that a higher hectarage of land be devoted to production to compensate for the rentals being charged by landlords if the enterprise was to remain profitable. The results of this study contrasted those of Rahman (2010) and Amare and Beyene (2015) which showed that lower size of cultivated land determined renting-in decisions. However, it is noted that for both Bangladesh and Ethiopia where the studies were done, the average size of land is about 3 hectares or less, which is far lower than what A1 and A2 farmers are allocated in Zimbabwe. This probably explains the differences in the results obtained in this study. Results presented in Table 3 also showed that perceptions of tenure security increased the likelihood of renting-in land. For those farmers without land and who were renting-in, perceptions of tenure certainty probably referred to their contractual agreements with the landlord, and not necessarily state tenure certainty. For those who were in investment partnerships, tenure security is enhanced by the formal agreements which were approved by the Ministry of Agriculture, reducing possible contractual violations in the process.

This result was however different from the findings by Shifa (2016) who observed no significant effect of tenure security in renting-in decisions. It is important to note that culture and social capital play an important role in production (Hou, Huo, and Yin 2017). Among those nations where private tenure has never been adopted, tenure security is enhanced by the time period one has been on the farm more than the documentation giving one access to land (Shifa 2016). Hence in such nations as Ethiopia, tenure certainty might not be important, while it is important in the Zimbabwean context. According to Bizimana (2011), a strong secured tenure reduces transaction costs associated with land rentals and in the process encourage participation in rental markets. Increasing the size of irrigated land by a hectare increases the likelihood of participating renting-in markets by 0.117 points. Irrigable size of land has the effect of increasing the probability of being involved in land renting-in. Where farmers had irrigable land, the risk of production is reduced, and it is expected that once irrigable land is available, then farmers become more interested in renting-in the land. Also, farmers who normally purchase irrigation facilities are resource endowed farmers who normally are more likely to seek more land for renting-in. The findings however differed from that of Rahman (2010) and Hou, Huo, and Yin (2017) which showed that irrigable land has no effect on renting-in decisions.

The decision by a farmer towards complete specialization in crop production as indicated by the crop diversification index had the effect of increasing the likelihood of renting-in land by 7.204 points. One of the tenets of commercial agriculture is specialization in limited enterprises (Rahman, 2010)). Farmers with a commercial approach to farming were more likely to seek more land to expand on production (Amare and Beyene 2015). It is therefore possible that farmers with such an orientation were inclined to seek more land for renting-in. A higher diversification index implied a propensity to specialize and consequently more demand for larger portions of land to practice agricultural production and hence renting-in behaviour. It is evident from the analysis that gender, household income and number of permanent labourers are household characteristics affecting the decision to rent-in land. Cultivated area, irrigable land size and crop diversification index represented land endowment factors while tenure security was a measure of transaction costs associated with the decision to rent-in land.

Determinants of Renting-Out (lessor) Decisions: The results of determinants of renting-out land showed that age, irrigable land size, crop diversification and permanent labour were significant factors. The first two factors were significant at 0.05 level of confidence while the last two were significant at 0.01 levels. It can be deduced that household characteristics and land endowments were the determining factors for farmer's decision to rent-out land. A decrease in age by one unit had the effect of increasing the likelihood of being involved in land rental markets by 0.239 points. Age is a culmination of the level of risk tolerance, agility to farm and farming experiences. Young farmers were more likely to take the risks of renting-out land if they were not fully utilizing it (Hou, Huo, and Yin 2017). Risk taking is naturally higher for the younger generation and in the face of conflicting political statements from policymakers, it was expected that young farmers were 
more involved in renting- out land compared to their older generation (Moyo 2016). The younger generation also does not have the capital to be fully engaged in agriculture (Matondi and Dekker 2011).

Furthermore, they constitute a large portion of the economically active group, preferring to seek formal employment in industry, thereby exhibiting a higher propensity towards unutilized, rented-out land. The results were supported by those of Masterson (2007); Amare and Beyene (2015); Nyangena (2014), who reported a significant and negative impact of age but contrasted with the findings of Bizimana (2011), whose conclusion was that age does not have a significant influence on the decision to rent-out land. The differences could have been accounted for by differences in the household characteristics. An increase in permanent labour by one unit also increased three times the probability of the farmer renting-out land. An increase in the irrigable land size by a unit also decreased the likelihood of a farmer renting-out land by 0.239 points. Increase in irrigable land size allowed the farmer to be efficient by maximizing output on a given piece of land (Hou, Huo, and Yin 2017). Hence, farmers were unlikely to rent-out land where there were irrigation facilities (Hou, Huo, and Yin 2017). Irrigation equipment was also expensive, and renting-out increased the risk of theft and misuse, hence the reluctance to rent-out irrigable land. This means that farmers who had irrigation facilities on their farms were unlikely to be renting-out land.

\section{Conclusion}

Increased specialization in crop production (crop diversification index) had the effect of increasing the probability of a farmer participating in renting-out of land by 17.6 points. These results were supported also by (Tikabo \& Holden, 2004)) but contrasted by the findings of a study by Rahman (2010). A farmer practising specializing is likely into commercial production and is therefore most probably to have a very limited amount of land to rent-out. The paper was aimed at understanding the determinants of the decisions to rent-in or rent-out land among A1 and A2 farmers. The bi-variate Tobit model results showed that the decision to rent-in land was influenced by gender, household income, permanent labour, cultivated area, tenure certainty, irrigable land size and the crop diversification index, which were statistically significant. Previous studies have shown no particular trend on the impacts of these variables on the renting-in decision. On the other hand, age, permanent labour, irrigable land size and crop diversification index significantly influenced the decisions to rent-out land. As with renting-in, literature has not shown any consistent tendencies for these variables. The conclusions were that household characteristics, land endowments and transaction costs significantly influenced renting-in decisions, while renting-out decisions were influenced more by household characteristics and land endowments. It is recommended that to improve land rental market participation, the following factors should be enhanced; income generation activities, promotion of capital-intensive technologies and irrigation facilities as well as improve the security of tenure.

\section{References}

Amare, A. \& Beyene, F. (2015). Determinants of Household Participation in Land Rental Markets in Amigna District, Arsi Zone of Oromiya Region, Ethiopia. Eastern Africa Social Science Research Review, 31(1), 21-42.

Awasthi, M. K. (2009). Dynamics and resource use efficiency of agricultural land sales and rental market in India. Land Use Policy, 26(3), 736-743.

Bert, F. et al. (2015). Simulating agricultural land rental markets by combining agent-based models with traditional economics concepts: The case of the Argentine Pampas. Environmental Modelling and Software, 71, 97-110.

Bizimana, C. (2011). Determinants of land rental markets: Theory and econometric evidence from rural Rwanda. Journal of Development and Agricultural Economics, 3(4), 183-189.

Chamberlin, J. \& Ricker-Gilbert, J. (2013). Participation in Rural Land Rental Markets in Sub-saharan Africa: Who Benefits and by How Much? Evidence from Malawi and Zambia. American Journal of Agricultural Economics, 1-33.

Deininger, K., Jin, S. \& Nagarajan, H. K. (2008). Efficiency and equity impacts of rural land rental restrictions: Evidence from India. European Economic Review, 52(5), 892-918.

Feng, S. (2008). Land rental, off-farm employment and technical efficiency of farm households in Jiangxi Province, China. NJAS - Wageningen Journal of Life Sciences, 55(4), 363-378. 


\section{Journal of Economics and Behavioral Studies (ISSN: 2220-6140)}

Vol. 10, No. 6, pp. 70-78, December 2018

Government of Zimbawe. (2016). Finance Bill, 2016, Zimbabwe: Government Gazette.

Hoken, H. (2012). Development of Land Rental Market and its Effect on Household Farming in Rural China: An Empirical Study in Zhejiang Province Hisat, Tokyo.

Holden, S. (2013). Efficiency and Productivity Differential Effects of Land Certification Program in Ethiopia, Norway.

Hou, J., Huo, X. \& Yin, R. (2017). Land rental market participation and its impact on fixed investment and household welfare: Evidence from Chinese apple production sites. Sustainability (Switzerland), 9(11).

Kimura, S. et al. (2011). Efficiency of Land Allocation through Tenancy Markets: Evidence from China. Economic Development and Cultural Change, 59(3), 485-510.

Lefever, S., Dal, M. \& Matthíasdóttir, Á. (2007). Online data collection in academic research: Advantages and limitations. British Journal of Educational Technology, 38(4), 574-582.

Mahari Tikabo, Stein Holden, O. B. (2011). Factor Market Imperfections and Land Rental Market in the Highlands of Eritrea : Theory and Evidence. Revised for Land economics, (October).

Masterson, T. (2007). Working Paper No . 491 Land Rental and Sales Markets in Paraguay by, New York.

Matondi, P. B. \& Dekker, M. (2011). Land rights and tenure security in Zimbabwe's post fast track Land Reform Programme., (March), p.47.

Moyo, S. (2007). Land in the Political Economy of African Development: Alternative Strategies for Reform, XXXII(4), 1-34.

Moyo, S. \& Chambati, W. (2013). Introduction : Roots of the Fast Track Land Reform in Zimbabwe. In S. Moyo \& W. Chambati, eds. Land and Agrarian Reform in Zimbabwe: Beyond White-Settler Capitalism. Dakar, Senegal: CODESRIA, 1-28.

Nyangena, W. (2014). Determinants of Household Participation in Land Rental Markets in Rural Kenya, Nairobi.

Rahman, S. (2010). Determinants of agricultural land rental market transactions in Bangladesh. Land Use Policy, 27(3), 957-964.

Reid, J. D. (2016). The Theory of Share Tenancy Revisited--Again Author ( s ): Joseph D . Reid , Jr . Published by: The University of Chicago Press Stable URL : http://www.jstor.org/stable/1830800 Accessed: 19-04-2016 11: 36 UTC Your use of the JSTOR archive indicates you, 85(2), 403-407.

Scoones, I. et al. (2011). Journal of Peasant Studies Zimbabwe â€ $€^{\mathrm{TM}} \mathrm{s}$ land reform : challenging the myths. The Journal of Peasant Studies, 38(5), 967-993.

Shifa, M. (2016). Determinants of Land and Labour Market Participation Decisions in Rural Ethiopia. Journal of African Development, 18(2), 73-90.

Vranken, L. \& Swinnen, J. (2006). Land rental markets in transition: Theory and evidence from Hungary. World Development, 34(3), 481-500.

Zimbabwe National Statistic Agency. (2012). Provincial report: Mashonaland Central, Harare. 